\title{
Contagion In MENA Countries During The 2008 Financial Meltdown
}

Loujaina El Sayed, American University in Cairo, Egypt

Nourhan Hegazi, American University in Cairo, Egypt

\begin{abstract}
Despite originating in the U.S., the repercussions of the 2008 global financial crisis were spread all over the globe to affect all classes of economies, suggesting the presence of a global contagious effect. MENA countries, which have recently become more integrated into the world economy, were also severely impacted. However, studying the contagious effect of the global financial crisis on MENA stock markets was not common in literature despite their importance for international diversification. This paper attempts to test for contagion from the U.S. to MENA equity markets during the 2008 global financial crisis using the change in correlations approach. We employ two models: the adjusted correlation model and the dynamic conditional correlations DCC-GARCH model. Results provide an evidence of the existence of contagion from the US to a number of MENA equity markets. The adjusted correlation model was proved to be biased towards the conclusion of "no contagion" when compared to the findings of the DCC-GARCH model.
\end{abstract}

Keywords: MENA Countries; 2008 Global Financial Crisis; Contagion

\section{INTRODUCTION}

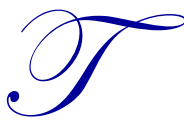

he 2008 global financial crisis is considered by many leading economists as the worst crisis since the Great Depression. Many factors catalyzed the emerging of the 2008 financial crisis; among which were credit market failure, inefficient regulatory framework and false anticipation of risk by credit rating agencies. As soon as the crisis manifested itself in the U.S., financial markets crashed, and its repercussions were spread to affect all economies, suggesting the presence of a global contagion effect. The MENA economies, among other global economies, were hardly hit by the 2008 financial crash, and the downside movement observed in the U.S. equity markets was soon reflected in MENA stock indices. But are these downside movements in MENA markets attributed to the existence of a global contagion effect, or just a result of normal interdependence?

Studying contagion in financial markets is crucial because of its implications on the monetary policy, asset pricing and international portfolio allocation. The definition of the term "financial contagion" is widely debatable in the literature. Most of the studies define contagion in terms of cross market correlations. For instance, Forbes and Rigobon (2002); and Kaminsky et al. (2003) identify contagion as the significant increase in cross market correlations over and above normal interdependence channels after a shock hits one country. Favero and Giavazzi (2002) opposed the use of the term contagion, as it does not describe the spillover of financial shocks since it overlooks the phenomenon of 'flight-to-quality' observed during financial crises. Thus, Sojli (2007) defined contagion as significant changes in either direction in cross market correlations to account for the possibility of the fall in cross-market correlations during the crisis period.

MENA markets have received little attention in attempting to investigate their vulnerability to external shocks, despite their increased integration in the global financial markets and the existence of diversification opportunities (Girard et al., 2003; Girard and Ferreira, 2004; and Lagoarde-Segot and Lucey, 2007). A notable study by Lagoarde-Segot and Lucey (2009) studied the repercussions of recent major financial crises on seven MENA markets starting with the 1997-98 Asian flu and ending by the global financial crisis of 2008. Results indicated that up to the Enron crisis, MENA markets were relatively immune. However, by the 2008 global financial crisis, most of the markets experienced the adverse effects of the crisis. 
Following Sojli's (2007) definition of contagion, this research attempts to fill the gap in the existing literature by investigating whether the downward trends in MENA equity markets during the 2008 global financial crisis were due to contagion effect. It builds on Lagoarde-Segot and Lucey (2009) by using a different definition of the crisis period that covers the whole crisis period as identified by the National Bureau of Economic Research. In addition, this study covers a larger sample of countries. The study employs two empirical models; the first is the adjusted correlation model due to Forbes and Rigobon (2002) that is heavily criticized in the literature for being biased towards the conclusion of "no contagion". The second model is the Dynamic Conditional Correlation model (DCC-GARCH) following Engle (2002). The paper is organized as follows. Sections II presents a brief review of the literature. Section III describes the data set used to test for contagion. Section IV and V outline the adjusted correlations model and the DCC-GARCH model, respectively, and present the empirical findings of each. Section VI compares the results of the two models and concludes.

\section{LITERATURE REVIEW}

The mechanism through which shocks are propagated across countries has been extensively examined in literature. The most significant channels through which shocks are propagated are bilateral and multilateral trade linkages and financial linkages ${ }^{1}$. In addition, the investors' behavior during crises can lead to excessive comovements in returns that are not a reflection of the fundamentals of the economy (Claessens and Forbes, 2004; and Calvo and Mendoza, 2000).

An extensive literature has been dedicated to examine markets co-movements in times of financial crises. The empirical models used include full information models (Favero and Giavazzi, 2002; and Dungey and Martin, 2004); volatility analysis based on ARCH/GARCH frameworks (Hamao et al., 1990; and Edwards, 1998); the cointegration theory ${ }^{2}$ (Longin and Solnik, 1995; and Masih and Masih, 1999); the co-breaking ${ }^{3}$ analysis (Ahlgren and Antell, 2010) and the copula models ${ }^{4}$ (Rodriguez, 2007)

The most commonly used methodology to test for contagion is the "cross-market correlation" method that is based on testing for significant increase/ change in cross market co-movements during crises periods compared to tranquil periods (King and Wadhawani, 1990; Lee and Kim, 1993; and Baig and Goldfajn, 1999). Yet, Forbes and Rigobon (2002) criticized cross market correlation models as they are conditional on market volatility, which leads to heteroscedasticity in residuals. Heteroscedasticity causes correlation coefficients to be biased upwards, confirming the existence of contagion. Forbes and Rigobon (2002) corrected for the heteroscedasticity bias by calculating unconditional cross-market correlation coefficients. Testing for contagion during the 1997 Asian crisis, 1994 Mexican devaluation and the 1987 U.S. market crash, the study concluded that there was a high level of market co-movements in all periods, which is only interdependence ${ }^{5}$ but not contagion. Forbes and Rigobon (2002) test was applied by different studies including Collins and Biekpe (2003), Collins and Gavron (2005); Sojli (2007); and Omri and Frikha (2011). Most of these studies did not find evidence on contagion.

Corsetti et al. (2005) criticized Forbes and Rigobon's (2002) methodology to adjust for heteroskedasticity, as it does not distinguish between common and country specific components of market returns; thus leading the test results to be biased towards "no contagion". Corsetti et al. (2005) proposed the use of a two-step conditional test,

\footnotetext{
${ }^{1}$ See Eichengreen et al. (1996); Glick and Rose (1998); Forbes (2001); and Hernandez and Valdes (2001) for the trade linkages. For the financial linkages and the "common bank lender" channels, see Calvo (1998); Valdes (2000); Van Rijckeghem and Weder (1999); and Kaminsky and Reinhart (2000).

2 This approach was criticized as it does not test for contagion directly, as co-integrating vectors test for relations over long periods, which could increase for reasons other than contagion.

${ }^{3}$ If two or more stationary time series have a break in their conditional means, but some linear combinations of these series do not have this break, then the series are said to be "co-breaking". Co-breaking can provide information about instantaneous spread of crises from one market to another.

${ }^{4}$ Copulas are defined as "functions that join or couple multivariate distribution functions to their one dimensional marginal distribution function". Copulas can capture non-linear dependence; as they contain information about the joint behavior of the random variables (Rodriguez, 2007).

${ }^{5}$ Forbes and Rigobon (2002) defined interdependence as the existence of high correlation among markets before financial crises; that do not increase after financial crises.
} 
which incorporate the time varying heteroskedastic variance into the cross market correlations. Having re-examined the Hong Kong 1997 stock market crisis, Corsetti et al. (2005) rejected the hypothesis of interdependence for five countries (compared to one country as per Forbes and Rigobon (2002) test).

Engle (2002) showed that correlation among asset returns is time varying; thus suggested the use of the Generalized Autoregressive Conditional Heteroscedastic (GARCH) model. He proposed the use of the Dynamic Conditional Correlation GARCH model (DCC-GARCH) to mitigate the dimensionality problems associated with GARCH models in estimating long time series. A substantial number of studies employed Engle's (2002) DCCGARCH model to test for contagion. According to Cho and Parhizgari (2008), DCC-GARCH is considered a superior measure of correlation because it continuously adjusts the correlation for the time-varying volatility. The model can detect changes in conditional correlations over time; and also investigate possible contagion effects due to herding behavior (Celik, 2012). Another advantage of the DCC-GARCH model is that it accounts for heteroskedasticity to remove any volatility bias, as volatility is continuously adjusted for in the estimation (Chiang et al., 2007). Yiu et al. (2010); Naoui et al. (2010); Syllignakis and Kouretas (2011); and Bouaziz et al. (2012) attempted to study the contagious effect from the US to a number of developed and emerging equity markets during the 2008 financial meltdown using the DCC-GARCH model; and found strong evidence of contagion. More recently, Celik (2012) studied the contagion effect of the crisis on foreign exchange markets in a number of developed and emerging countries and found some evidence on contagion, with emerging economies being more adversely impacted by the crisis.

\section{DATA}

We use daily closing prices of 11 stock market indices (denominated in local currencies) for the period from January $1^{\text {st }}$, 2005 till July $31^{\text {st }}$, 2009. Index prices were obtained from both Datastream and CEIC Data Manager and were transformed into log returns. Returns of the following markets were used:

$\begin{array}{ll}\text { S\&P 500 } & \text { New York Stock Exchange } \\ \text { EGX 30 } & \text { Egyptian Stock Exchange } \\ \text { MASI } & \text { Moroccan Casablanca Stock Exchange } \\ \text { TUNINDEX } & \text { Tunisia Stock Exchange } \\ \text { TASI } & \text { Saudi Tadawul Stock Exchange } \\ \text { KWSE } & \text { Kuwaiti Stock Exchange } \\ \text { MSM 30 } & \text { Omani Muscat Stock Exchange } \\ \text { BAHRAIN All SHARE } & \text { Bahrain Stock Exchange } \\ \text { ASE } & \text { Jordanian Amman Stock Exchange } \\ \text { TA-100 } & \text { Israeli Tel Aviv Stock Exchange } \\ \text { ADX } & \text { Abu Dhabi Securities Exchange } \\ \text { Qatar General Index } & \text { Qatari Stock Exchange }\end{array}$

In literature, determining the crisis period is very controversial. In this study, we follow the National Bureau of Economic Research (NBER); identifying the crisis period to range from September 2008 till July $2009^{6}$ (Business Cycle Dating Committee, 2011).

Tables (1) and (2) below summarize the key statistics of the indices used in the tranquil and crisis period respectively. During the tranquil period, all markets under study had positive average daily returns, with Egypt recording the highest average return. Jordan exhibited the highest volatility in its daily returns, followed by Saudi

\footnotetext{
${ }^{6}$ According to the Business Cycle Dating Committee of NBER, December 2007 was identified as the peak of economic activity in the US, where it marked the end of a boom that began in November 2001 and the beginning of a recession. According to the Committee's report, product-side estimates of the US economy fell slightly in 2007Q4, but rose again slightly in 2008Q1, and rose further in in 2008Q2. However, it started to fall in 2008Q3. Also, income-side estimates reached their peak in 2007Q3, fell slightly in 2007Q4 and 2008Q1, but slightly increased again in 2008Q2. It started to fall again in 2008Q3. Thus, the beginning of the actual crisis can be dated as 2008Q3 (September 2008). Furthermore, the Business Cycle Dating Committee marked the trough of business activity in the US to be June 2009, after which economic activities started to pick up again.
} 
Arabia. Returns of all countries are negatively skewed, with the exception of Tunisia, Bahrain and Abu Dhabi. Moreover, findings of the Jarque-Bera test indicate that daily returns of all markets are non-normally distributed. During the crisis period, the daily average returns of all markets examined were negative, with the exception of Tunisia. Volatility in all markets was higher relative to the tranquil period, with the Egyptian market exhibiting the highest volatility in daily returns. Returns of almost all markets during the crisis period were non-normally distributed, except Kuwait, Qatar and Jordan.

Missing observations in daily returns due to weekends and official holidays were treated using a rolling average of the two days preceding the missing observation. Results of the other methods for treating missing observations are reported in the robustness checks for both models (sections 4.3 and 5.3).

\section{THE ADJUSTED CORRELATION MODEL}

\section{The Model}

A vector autoregressive (VAR) model is used to control for serial correlation and any exogenous global shocks, as follows:

$$
\begin{gathered}
X_{t}=\Phi(L) X_{t}+\phi(L) S_{t}+\eta_{t} \\
\mathrm{X}_{\mathrm{t}}=\left\{\mathrm{x}_{\mathrm{t}}^{\mathrm{US}}, \mathrm{x}_{\mathrm{t}}^{\mathrm{j}}\right\} \\
\mathrm{S}_{\mathrm{t}}=\left\{\mathrm{i}_{\mathrm{t}}^{\mathrm{US}}, \mathrm{ms}_{\mathrm{t}}^{\mathrm{j}}, \mathrm{o}_{\mathrm{t}}\right\}
\end{gathered}
$$

where $x_{t}^{U S}$ is the stock market $\log$ return in the U.S. (crisis country); $x_{t}^{j}$ is the stock market log return in the other markets j; $\Phi(L)$ and $\phi(L)$ are vectors of lags; and $S_{t}$ is a matrix that captures exogenous effects and $\eta_{\mathrm{t}}$ is the vector of reduced form disturbances. 
Table 1: Descriptive Statistics for Tranquil Period Returns (Jan. 1st, 2005 till Aug. 31st, 2008)

\begin{tabular}{|c|c|c|c|c|c|c|c|c|c|c|}
\hline & No of Obs. & Mean & Median & Maximum & Minimum & Std. Dev. & Skewness & Kurtosis & Jarque-Bera & Prob. \\
\hline S\&P 500 & 922 & $6.17 \mathrm{E}-05$ & 0.000779 & 0.041535 & -0.03534 & 0.009102 & -0.1648 & 5.122197 & 177.1914 & 0 \\
\hline EGX 30 & 901 & 0.001303 & 0.00213 & 0.06837 & -0.07931 & 0.016875 & -0.35138 & 5.378179 & 230.867 & 0 \\
\hline MASI & 915 & 0.001234 & 0.001399 & 0.035535 & -0.05017 & 0.009395 & -0.59065 & 6.974243 & 655.3715 & 0 \\
\hline TUNINDEX & 905 & 0.001011 & 0.000741 & 0.036133 & -0.02125 & 0.004885 & 0.655335 & 8.348025 & 1143.287 & 0 \\
\hline TASI & 937 & $7.43 \mathrm{E}-05$ & 0.001769 & 0.093907 & -0.10099 & 0.020995 & -0.82119 & 7.370477 & 851.0479 & 0 \\
\hline KWSE & 904 & 0.000899 & 0.001316 & 0.050469 & -0.03737 & 0.007943 & -0.24361 & 7.423614 & 746.016 & 0 \\
\hline MSM 30 & 870 & 0.001204 & 0.001066 & 0.047964 & -0.08699 & 0.010327 & -0.75539 & 12.52492 & 3371.491 & 0 \\
\hline BAHRAIN All SHARE & 906 & 0.000457 & $-2.26 \mathrm{E}-05$ & 0.036132 & -0.02587 & 0.00619 & 0.514954 & 7.281488 & 732.0424 & 0 \\
\hline ASE & 855 & $3.40 \mathrm{E}-05$ & 0.000994 & 0.068164 & -0.64804 & 0.026123 & -17.878 & 444.5453 & 6991076 & 0 \\
\hline TA-100 & 903 & 0.000396 & 0.000892 & 0.037609 & -0.04647 & 0.010924 & -0.60424 & 4.938284 & 196.3034 & 0 \\
\hline ADX & 884 & 0.000454 & $-4.79 E-05$ & 0.090648 & -0.08649 & 0.015614 & 0.423055 & 9.977118 & 1819.422 & 0 \\
\hline Qatar General Index & 922 & 0.000515 & 0.000323 & 0.058158 & -0.08074 & 0.015965 & -0.13389 & 4.655509 & 108.044 & 0 \\
\hline
\end{tabular}

Table 2: Descriptive Statistics for Crisis Period Returns (Sep 1st, 2008 till Jul 31st, 2009)

\begin{tabular}{|c|c|c|c|c|c|c|c|c|c|c|}
\hline & No of Obs. & Mean & Median & Maximum & Minimum & Std. Dev. & Skewness & Kurtosis & Jarque-Bera & Prob. \\
\hline S\&P 500 & 231 & -0.00113 & 0.001215 & 0.109572 & -0.094695 & 0.029629 & -0.05005 & 4.720116 & 28.57488 & 0 \\
\hline EGX 30 & 223 & -0.00141 & 0.000978 & 0.063388 & -0.17986 & 0.030113 & -1.17486 & 7.859175 & 270.6922 & 0 \\
\hline MASI & 228 & -0.00107 & -0.000187 & 0.044635 & -0.046656 & 0.012892 & -0.31164 & 5.24295 & 51.48345 & 0 \\
\hline TUNINDEX & 228 & 0.000383 & 0.000697 & 0.029373 & -0.050037 & 0.007741 & -1.43791 & 13.45444 & 1116.874 & 0 \\
\hline TASI & 227 & -0.00183 & 0.000651 & 0.090874 & -0.103285 & 0.027593 & -0.33742 & 5.284662 & 53.67684 & 0 \\
\hline KWSE & 225 & -0.00281 & -0.000672 & 0.038026 & -0.038745 & 0.013838 & -0.14987 & 3.198623 & 1.212189 & 0.5455 \\
\hline MSM 30 & 224 & -0.00216 & -0.000448 & 0.080388 & -0.08651 & 0.026212 & -0.25828 & 4.660701 & 28.2312 & 0 \\
\hline BAHRAIN All SHARE & 225 & -0.00263 & -0.001935 & 0.026217 & -0.0492 & 0.010029 & -0.80463 & 5.542577 & 84.88496 & 0 \\
\hline ASE & 224 & -0.00229 & -0.000944 & 0.046088 & -0.043779 & 0.016235 & -0.03199 & 3.212285 & 0.458834 & 0.7950 \\
\hline TA-100 & 221 & $-7.2 \mathrm{E}-05$ & 0.000697 & 0.097815 & -0.073416 & 0.024269 & -0.02882 & 4.069232 & 10.55807 & 0.0051 \\
\hline ADX & 224 & -0.00203 & -0.000115 & 0.07258 & -0.066486 & 0.020752 & -0.07070 & 4.412204 & 18.80027 & 0.0001 \\
\hline Qatar General Index & 231 & -0.00192 & 0.000567 & 0.094223 & -0.093581 & 0.03128 & -0.08141 & 3.839388 & 7.0366 & 0.0297 \\
\hline
\end{tabular}


The matrix $S_{t}$ includes two important exogenous factors that have an impact of equity returns in MENA markets; the change in oil prices $\left(\mathrm{o}_{t}\right)$ and the monetary response to the shocks. Given that oil constitutes the largest share of total MENA countries exports, changes in the international oil prices have significant impacts on MENA economies; thus need to be accounted for in the model. The second factor is the monetary policy response to the crisis in both the US and the MENA markets under investigation. During crises, monetary policy becomes a significant tool used to mitigate the negative impact of the crisis. During the 2008 crisis, most central banks of MENA countries relaxed their monetary policies in an attempt to foster growth to their economies (Kouame, 2009). Thus, the short term interest rates in the U.S. $\left(i_{t}^{U S}\right)$ and the log change in money supply in MENA countries under study $\left(\mathrm{ms}_{\mathrm{t}}^{\mathrm{j}}\right)$ were incorporated in the model to account for monetary policy response ${ }^{7}$.

The VAR model is estimated for the US market returns and each of markets under study during the stable and turbulent periods to obtain cross-market correlation coefficients among the residuals. Following Forbes and Rigobon (2002), cross market conditional correlations were adjusted for the heteroscedasticity bias using the following formula:

$$
\rho=\frac{\rho *}{\sqrt{1+\delta\left[1-(\rho *)^{2}\right]}}
$$

where $\delta$ is the relative increase in the variance of returns $\mathrm{x}$ during the crisis (measured as $\left.\left(\sigma_{\mathrm{xx}}^{\mathrm{h}} / \sigma_{\mathrm{xx}}^{\mathrm{I}}\right)-1\right)$; where $\sigma_{\mathrm{xx}}^{\mathrm{h}}$ is the variances of high variance group (crisis period), $\sigma_{\mathrm{xx}}^{\mathrm{l}}$ is the variance of low variance group (tranquil period), and $\rho *$ is the conditional correlation obtained from the VAR estimation. Finally, we test for the significance of the change in unconditional correlation from the stable to the turbulent periods:

$$
H_{o}: \Delta \rho=0
$$

whereby the t-statistic for testing this hypothesis is given by the equation:

$$
t=\frac{\rho_{c}-\rho_{t}}{\sqrt{\left(\frac{1}{N_{c}}\right)+\left(\frac{1}{N_{t}}\right)}}
$$

where $\rho_{c}$ and $\rho_{t}$ are the correlation coefficients during the crisis and tranquil periods respectively; and $N_{c}$ and $N_{t}$ are the number of observations during the crisis and the tranquil periods.

\section{Estimation and Results}

The VAR model was estimated to obtain the correlation coefficients among residuals for both the tranquil period (from January $1^{\text {st }}, 2005$ till August 31 $1^{\text {st }}, 2008$ ), and the turbulent period (from September $1^{\text {st }}$, 2008 till July $31^{\text {st }}$, 2009). The optimal lag structure was determined according to Schwarz Information Criteria (SC). The unconditional and conditional correlation coefficients were calculated and reported in tables (3) and (4) below.

\footnotetext{
${ }^{7}$ For the changes in international oil prices $o_{t}$, the change in the daily price of the West Texas Intermediate (WTI) crude oil, obtained directly from the U.S. Energy Information Administration (EIA) website was used. The three month Treasury Bills rate was used as a proxy for monetary policy response in the U.S. For MENA countries, the change in daily money supply was used to account for monetary policy response to the shock. The rationale is that other monetary variables (interest rates and exchange rates) are almost fixed in MENA countries; thus, they cannot be used to control for the response of monetary authorities in the examined countries. Monthly observations on M2 in MENA countries were obtained from DataStream and were converted to daily observations via the low-to-high frequency conversion options in E-views.
} 
Table 3: Unadjusted Correlation Coefficients of Market Returns

\begin{tabular}{|c|c|c|c|c|c|c|}
\hline & \multicolumn{2}{|c|}{ Tranquil } & \multicolumn{2}{|c|}{ Crisis } & \multirow[t]{2}{*}{ t-statistic } & \multirow[t]{2}{*}{ Contagion } \\
\hline & p & $\sigma$ & o & $\sigma$ & & \\
\hline Egypt & 0.053 & 0.015 & 0.226 & 0.024 & 2.821 & $\mathrm{C}$ \\
\hline Morocco & -0.010 & 0.008 & 0.114 & 0.011 & 2.030 & $\mathrm{C}$ \\
\hline Tunisia & 0.048 & 0.004 & -0.042 & 0.007 & -1.476 & $\mathrm{~N}$ \\
\hline Saudi Arabia & 0.001 & 0.018 & 0.231 & 0.024 & 3.767 & $\mathrm{C}$ \\
\hline Kuwait & 0.038 & 0.007 & 0.016 & 0.011 & -0.366 & $\mathrm{~N}$ \\
\hline Oman & 0.015 & 0.009 & 0.057 & 0.021 & 0.695 & $\mathrm{~N}$ \\
\hline Bahrain & 0.037 & 0.005 & -0.012 & 0.009 & -0.804 & $\mathrm{~N}$ \\
\hline Jordan & 0.012 & 0.011 & 0.092 & 0.012 & 1.312 & $\mathrm{~N}$ \\
\hline Israel & 0.275 & 0.010 & 0.231 & 0.022 & -0.726 & $\mathrm{~N}$ \\
\hline Abu Dhabi & -0.018 & 0.013 & 0.210 & 0.016 & 3.729 & $\mathrm{C}$ \\
\hline Qatar & -0.007 & 0.013 & 0.096 & 0.025 & 1.675 & $\mathrm{C}$ \\
\hline
\end{tabular}

$\rho$ and $\sigma$ are, respectively, the correlation coefficients and the standard deviation of the residuals; and $\mathrm{C}$ represents contagion and $\mathrm{N}$ represents no contagion.

Table 4: Adjusted Correlation Coefficients of Market Returns

\begin{tabular}{|c|c|c|c|c|c|c|}
\hline & \multicolumn{2}{|c|}{ Tranquil } & \multicolumn{2}{|c|}{ Crisis } & \multirow[t]{2}{*}{ t-statistic } & \multirow[t]{2}{*}{ Contagion } \\
\hline & $\rho$ & $\sigma$ & $\rho$ & $\sigma$ & & \\
\hline Egypt & 0.033 & 0.015 & 0.140 & 0.024 & 1.760 & $\mathrm{C}$ \\
\hline Morocco & -0.008 & 0.008 & 0.084 & 0.011 & 1.494 & $\mathrm{~N}$ \\
\hline Tunisia & 0.029 & 0.004 & -0.026 & 0.007 & -0.89489 & $\mathrm{~N}$ \\
\hline Saudi Arabia & 0.001 & 0.018 & 0.176 & 0.024 & 2.863 & $\mathrm{C}$ \\
\hline Kuwait & 0.024 & 0.007 & 0.010 & 0.011 & -0.227 & $\mathrm{~N}$ \\
\hline Oman & 0.006 & 0.009 & 0.024 & 0.021 & 0.290 & $\mathrm{~N}$ \\
\hline Bahrain & 0.024 & 0.005 & -0.008 & 0.009 & -0.510 & $\mathrm{~N}$ \\
\hline Jordan & 0.011 & 0.011 & 0.083 & 0.012 & 1.186 & $\mathrm{~N}$ \\
\hline Israel & 0.127 & 0.010 & 0.105 & 0.022 & -0.351 & $\mathrm{~N}$ \\
\hline Abu Dhabi & -0.015 & 0.013 & 0.179 & 0.016 & 3.168 & $\mathrm{C}$ \\
\hline Qatar & -0.004 & 0.013 & 0.052 & 0.025 & 0.909 & $\mathrm{~N}$ \\
\hline
\end{tabular}

$\rho$ and $\sigma$ are, respectively, the correlation coefficients and the standard deviation of the residuals; and C represents contagion and $\mathrm{N}$ represents no contagion.

According to the unadjusted correlation coefficients from the VAR model (table 3), contagion (defined as significant change in correlation coefficients during the crisis) was reported in Egypt, Morocco, Saudi Arabia, Abu Dhabi and Qatar. When adjusting the correlation coefficients for heteroskedasticity bias (table 4), results revealed that Egypt, Saudi Arabia and Abu Dhabi had contagion effect; while the rest of the countries under investigation exhibited only normal interdependence. The significant increase in correlation between the US and Saudi Arabia can be attributed to the trade linkages channel; since Saudi Arabia is the largest oil exporter to the US among the MENA countries. Meanwhile, the contagion observed in Egypt and Abu Dhabi can be explained in the context of investors' behavior when responding to the crisis. Losses in the U.S. may have induced international investors to sell securities in other markets in order to raise cash. Asymmetric information about individual markets triggers the "herd behavior" among other investors, which intensifies the propagation of the crisis across markets. The "herd behavior" approach can also explain the contagious effect of the crisis in other MENA countries.

\section{Robustness Checks}

Several robustness checks related to the method of treating missing observations were carried out to validate the sensitivity of the reported results ${ }^{8}$. Following Sojli (2007), missing observations were treated as days with zero return. Estimation using this method supports the previously obtained results of the existence of contagion in Egypt, Saudi Arabia and Abu Dhabi. Furthermore, under this method, contagion was also reported in Morocco. Using a two-day rolling average for the whole dataset to account for missing observations and the impact of different trading timing in different markets, results indicated that Egypt, Morocco, Saudi Arabia, Jordan and Abu

${ }^{8}$ Detailed results can be provided by the authors upon request

2013 The Clute Institute $\quad$ Copyright by author(s) Creative Commons License CC-BY 
Dhabi exhibited significant change in correlation during the crisis ${ }^{9}$.

\section{THE DYNAMIC CONDITIONAL CORRELATION (DCC-GARCH) MODEL}

As previously mentioned, the DCC-GARCH model has a number of advantages over Forbes and Rigobon's (2002) adjusted correlation model. It continuously adjusts the correlation for the time-varying volatility; as it can detect changes in conditional correlations over time (Celik, 2012). Moreover, the DCC-GARCH model accounts for heteroskedasticity to remove any volatility bias, as volatility is continuously adjusted for in the estimation (Chiang et al, 2007).

\section{The Model}

The estimation of Engle's (2002) DCC-GARCH model involves two steps. The first step involves estimating a GARCH model for all return series. A univariate GARCH $(1,1)$ model for any return series $X_{i}$ is expressed as:

$$
\begin{gathered}
X_{i, t}=\phi_{0}+\sum_{k=1}^{p} \phi_{1, k} X_{t-k}+\varepsilon_{1, t} \\
h_{11, t}=\alpha_{10}+\alpha_{11} \varepsilon_{1, t-1}^{2}+\beta_{11} h_{11, t-1}
\end{gathered}
$$

The second step involves estimating the conditional correlations between standardized residuals that vary over time. According to Celik (2012), the DCC-GARCH model is expressed as follows:

$$
\begin{gathered}
X_{t}=\mu_{t}+H_{t}^{1 / 2} \varepsilon_{t} \\
H_{t}=D_{t} R_{t} D_{t} \\
\left\{\begin{array}{c}
\left.\operatorname{diag}\left(Q_{t}\right)\right)^{-1 / 2} Q_{t}\left(\operatorname{diag}\left(Q_{t}\right)\right)^{-1 / 2} \\
R_{t}=\left(\operatorname{diag}\left(\sqrt{h_{11, t}}, \sqrt{h_{22, t}}, \ldots, \sqrt{h_{N N, t}}\right)\right. \\
D_{t}=\operatorname{diag}
\end{array}\right.
\end{gathered}
$$

where $X_{t}=\left(X_{1 t}, X_{2 t}, \ldots, X_{N t}\right)$ is the vector of past observations; $\mu_{t}=\left(\mu_{1 t}, \mu_{2 t}, \ldots, \mu_{N t}\right)$ is the vector of conditional returns; $H_{t}$ is the multivariate conditional variance; $\varepsilon_{t}=\left(\varepsilon_{1 t}, \varepsilon_{2 t}, \ldots, \varepsilon_{N t}\right)$ is the vector of standardized residuals; $R_{t}$ is a $\mathrm{N}$ x $\mathrm{N}$ symmetric dynamic correlations matrix; and $D_{t}$ is a diagonal matrix of time varying standard deviations for return series, obtained from estimating the univariate GARCH model, where $\sqrt{h_{i i, t}}$ is on the $\mathrm{i}^{\text {th }}$ diagonal, $\mathrm{i}=1,2$, $\ldots, \mathrm{N}$. The DCC specification is defined as follows:

$$
\begin{gathered}
Q_{t}=(1-\alpha-\beta) \check{Q}+\beta Q_{t-1}+\alpha \delta_{i, t-1} \delta_{j, t-1} \\
R_{t}=Q_{t}^{*-1} Q_{t} Q_{t}^{*-1}
\end{gathered}
$$

where $\left(Q_{t}\right)=\left\lfloor q_{i j, t}\right\rfloor$ is $(\mathrm{N} \times \mathrm{N})$ time varying covariance matrix of standardized residuals $\left(\delta_{i t}=\frac{\varepsilon_{i t}}{\sqrt{h_{i t}}}\right)$; $\check{Q}$ is the unconditional correlations of $\delta_{i, t} \delta_{j, t} ; \alpha$ and $\beta$ are non-negative scalar parameters that satisfy $\alpha+\beta<1$; and $Q_{t}^{*}=\left[q_{i i, t}^{*}\right]=\sqrt{q_{i i, t}}$ is a diagonal matrix with the square root of the $\mathrm{i}^{\text {th }}$ diagonal element of $Q_{t}$ on its $\mathrm{i}^{\text {th }}$ diagonal position. Thus, for a pair of markets $i$ and $j$, the conditional correlation at time $(t)$ is:

$$
\rho_{\mathrm{ij}, \mathrm{t}}=\frac{(1-\alpha-\beta) \widetilde{\mathrm{q}_{\mathrm{ij}}}+\alpha \delta_{\mathrm{i}, \mathrm{t}-1} \delta_{\mathrm{j}, \mathrm{t}-1}+\beta \mathrm{q}_{\mathrm{ij}, \mathrm{t}-1}}{\left[(1-\alpha-\beta) \check{\rho}_{\mathrm{ij}}+\alpha \delta_{\mathrm{i}, \mathrm{t}-1}^{2}+\beta \mathrm{q}_{\mathrm{ii}, \mathrm{t}-1}\right]^{1 / 2}\left[(1-\alpha-\beta) \check{\rho}_{\mathrm{jj}}+\alpha \delta_{\mathrm{j}, \mathrm{t}-1}^{2}+\beta \mathrm{q}_{\mathrm{j}, \mathrm{t}-1}\right]^{1 / 2}}
$$

where $q_{i j}$ is the element on the $\mathrm{i}^{\text {th }}$ line and the $\mathrm{j}^{\text {th }}$ column of the matrix $Q_{t}$.

The parameters are estimated using a quasi-maximum likelihood method, with the following likelihood function:

\footnotetext{
9 The drawback of treating missing observations as days with zero returns is that it creates artificial volatility in the dataset. Moreover, using a two-day rolling average for the whole dataset leads to a very high autocorrelation in the dataset, which necessitates the use of a larger number of lags.
} 


$$
L(\theta)=-\frac{1}{2} \sum_{t=1}^{T}\left[\left(n \log (2 \pi)+\log \left|D_{t}\right|^{2}+\varepsilon_{t}^{\prime} D_{t}^{-1} D_{t}^{-1} \varepsilon_{t}\right)+\left(\log \left|R_{t}\right|+\delta_{t}^{\prime} R_{t}^{-1} \delta_{t} \delta_{t}^{\prime} \delta_{t}\right)\right]
$$

Following Celik (2012), the t-test is used to test for the increase in the dynamic correlation coefficients in the tranquil and crisis periods. The null hypothesis is

$$
\mathrm{H}_{\mathrm{o}}: \mu_{\rho}^{\mathrm{c}}=\mu_{\rho}^{\mathrm{t}}
$$

where $\mu_{\rho}^{\mathrm{c}}$ and $\mu_{\rho}^{\mathrm{t}}$ are the conditional correlation coefficient means of population in the crisis and tranquil periods respectively.

If the sample sizes are $n_{c}$ and $n_{t}$, the population variances $\sigma_{c}^{2}$ and $\sigma_{t}^{2}$ are different and unknown. If the means of dynamic correlation coefficients estimated by DCC are $\check{\rho}_{\mathrm{ij}}^{\mathrm{c}}$ and $\check{\rho}_{\mathrm{ij}}^{\mathrm{t}}$ for the crisis and tranquil periods respectively; and the variances are $\mathrm{s}_{\mathrm{c}}^{2}$ and $\mathrm{s}_{\mathrm{t}}^{2}$, then the t-statistic is calculated as: $t=\frac{\left(\check{\rho}_{\mathrm{ij}}^{\mathrm{c}}-\breve{\rho}_{\mathrm{ij}}^{\mathrm{t}}\right)-\left(\mu_{\rho}^{c}-\mu_{\rho}^{t}\right)}{\sqrt{\frac{s_{c}^{2}}{n^{c}}+\frac{s_{t}^{2}}{n^{t}}}}$

where $s_{\mathrm{c}}^{2}=\frac{1}{\mathrm{n}^{\mathrm{c}}-1} \sum_{\mathrm{t}=1}^{\mathrm{n}^{\mathrm{c}}}\left(\rho_{\mathrm{ij}}^{\mathrm{c}}-\widetilde{\rho_{\mathrm{lj}}^{\mathrm{c}}}\right)^{2}$ and $\mathrm{s}_{\mathrm{t}}^{2}=\frac{1}{\mathrm{n}^{\mathrm{t}}-1} \sum_{\mathrm{t}=1}^{\mathrm{n}^{\mathrm{t}}}\left(\rho_{\mathrm{ij}}^{\mathrm{t}}-\widetilde{\rho_{\mathrm{lj}}^{\mathrm{t}}}\right)^{2}$

The degree of freedom $v$ is: $v=\frac{\left(\frac{s_{c}^{2}}{n^{c}}+\frac{s_{t}^{2}}{n^{t}}\right)^{2}}{\frac{\left(s_{c}^{2} / n_{c}\right)^{2}}{n^{c}-1}+\frac{\left.s_{t}^{2} / n_{t}\right)^{2}}{n^{t}-1}}$

\section{Estimation and Results}

The computed dynamic conditional correlations are graphed in figure (1) below, where the beginning of the crisis period is indicated by the vertical red line. Table (5) depicts mean of the dynamic conditional correlations in the tranquil and turbulent periods $\left(\breve{\rho}_{\mathrm{ij}}^{\mathrm{t}}\right.$ and $\left.\breve{\rho}_{\mathrm{ij}}^{\mathrm{c}}\right)$ and the results of the T-test for contagion. DCC correlations mean value increased during the crisis period for all countries, except Morocco, Tunisia, Oman, and Bahrain. Abu Dhabi and Jordan seem to be the most influenced by the contagion effect, since the DCC correlations for both markets increased notably during the crisis. Findings of the T-test show that we cannot reject the null hypothesis of the mean of DCC correlations are the same in crisis and tranquil periods for Morocco, Tunisia and Oman. On the other hand, we do reject the null hypothesis for Egypt, Saudi Arabia, Kuwait, Jordan, Israel, Bahrain, Abu Dhabi and Qatar. It is worth noting that although the mean of the dynamic correlations decreased in Bahrain after the crisis, the t-statistic is significant at $10 \%$. Thus, we reject the null hypothesis of no contagion as it presents the flight-to-quality phenomenon that occurs during crises.

Table 3: Mean of DCC Correlations and T-test Results

\begin{tabular}{|l|c|c|c|c|c|c|c|}
\hline \multirow{2}{*}{ Egypt } & \multicolumn{2}{|c|}{ Tranquil } & \multicolumn{2}{c|}{ Crisis Difference } & \multirow{2}{*}{ T-statistic } & \multirow{2}{*}{ Contagion } \\
\cline { 2 - 7 } & $\check{\boldsymbol{\rho}}_{\mathbf{i j}}^{\mathbf{z}}$ & $\boldsymbol{\sigma}_{\boldsymbol{t}}$ & $\check{\boldsymbol{\rho}}_{\mathbf{i j}}^{\mathbf{c}}$ & $\boldsymbol{\sigma}_{\boldsymbol{c}}$ & & & \\
\hline Morocco & 0.0735 & 0.0501 & 0.0822 & 0.0656 & 11.91 & 2.437 & $\mathbf{C}$ \\
\hline Tunisia & -0.0135 & 0.0245 & -0.0128 & 0.0405 & -5.20 & 0.316 & $\mathbf{N}$ \\
\hline Saudi Arabia & 0.0131 & 0.0348 & 0.0124 & 0.0445 & -4.95 & -0.266 & $\mathbf{N}$ \\
\hline Kuwait & 0.0503 & 0.0155 & 0.0569 & 0.0191 & 13.16 & 6.333 & $\mathbf{C}$ \\
\hline Oman & 0.0417 & 0.0303 & 0.0458 & 0.0413 & 9.97 & 1.839 & $\mathbf{C}$ \\
\hline Bahrain & 0.0312 & 0.0412 & 0.0300 & 0.0546 & -3.66 & -0.381 & $\mathbf{N}$ \\
\hline Jordan & 0.0414 & 0.0169 & 0.0335 & 0.0193 & -19.15 & -7.495 & $\mathbf{C}$ \\
\hline Israel & 0.0181 & 0.0380 & 0.0233 & 0.0469 & 28.46 & 2.005 & $\mathbf{C}$ \\
\hline Abu Dhabi & 0.2660 & 0.0237 & 0.2690 & 0.0223 & 1.11 & 2.422 & $\mathbf{C}$ \\
\hline Qatar & 0.0092 & 0.0118 & 0.0128 & 0.0144 & 39.85 & 4.633 & $\mathbf{C}$ \\
\hline
\end{tabular}

$\breve{\rho}_{\mathrm{ij}}^{\mathrm{t}}, \breve{\rho}_{\mathrm{ij}}^{\mathrm{c}}, \sigma_{t}$ and $\sigma_{c}$ are, respectively, the correlation coefficients and the standard deviation of the residuals for the tranquil and the crisis period; $\mathrm{C}$ represents contagion and $\mathrm{N}$ represents no contagion. 

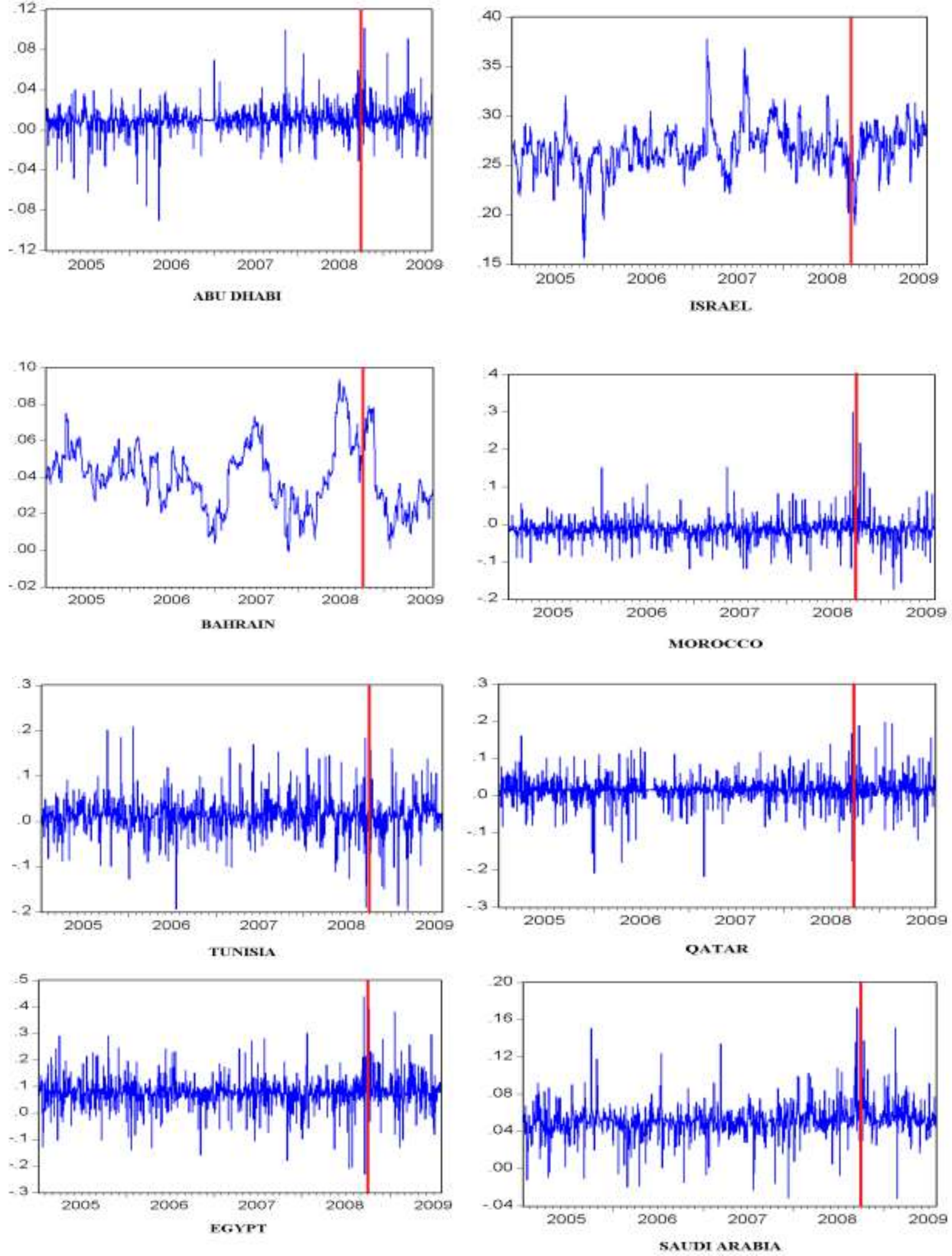

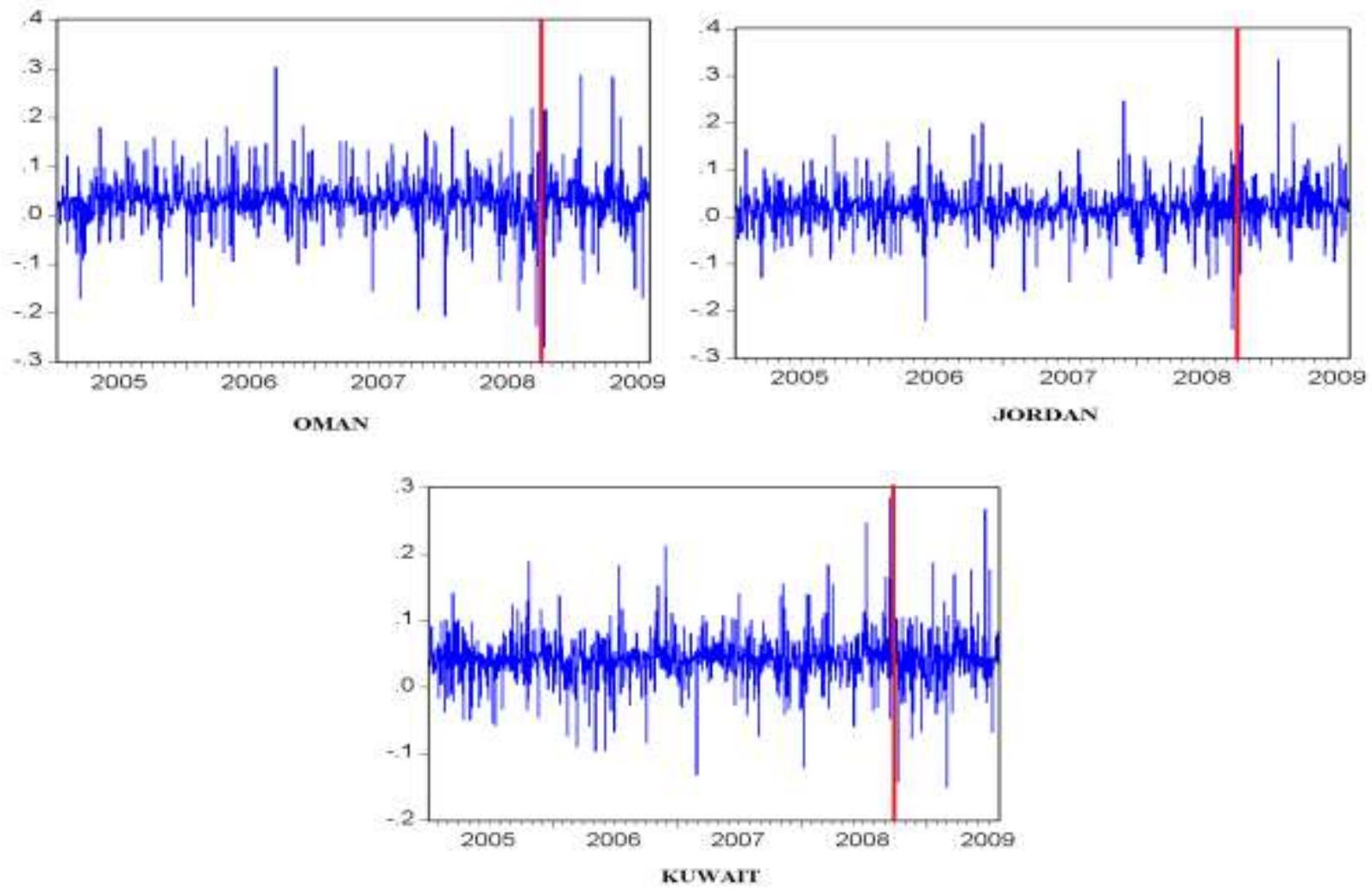

Figure 1: The Estimated Dynamic Conditional Correlations

\section{Robustness Checks}

The same robustness checks were carried out to validate the sensitivity of the DCC-GARCH model results. Accounting for missing observations as days with zero returns resulted in contagion being reported in all countries under study, with the exception of Bahrain, Morocco and Tunisia. On the other hand, using a two-day rolling average for the whole dataset yielded results that are robust to the results of the zero return treatment.

\section{CONCLUDING REMARKS: THE ADJUSTED CORRELATION MODEL VERSUS THE DCC-GARCH MODEL}

Defining contagion as a significant change in cross market correlations during periods of financial crises, two models were employed to study the impact of the 2008 global financial meltdown on selected MENA equity markets. Both models measure the impact of shocks by relying on changes in the correlation coefficients of the residuals. Table (6) below summarizes the contagion versus no contagion results in the 11 markets under study using both the adjusted correlation model and the DCC-GARCH model.

According to the adjusted correlations model, the null hypothesis of no contagion was rejected for only three markets. Results were not robust when changing the treatment of missing observations as evidence of contagion appeared in more countries. Meanwhile, results of the DCC-GARCH model indicated that contagion existed in eight countries; and also results were not robust to changing the method of treating missing observations. This confirms the criticism that the adjusted correlations model is biased towards the conclusion of "No Contagion" (Corsetti et al., 2005). 
Table 4: Adjusted Correlation Model vs. DCC-GARCH model: Comparing Results

\begin{tabular}{|l|c|c|}
\hline & Results based on Adjusted Correlation Model & Results based on the DCC-GARCH Model \\
\hline Egypt & $\mathrm{C}$ & $\mathrm{C}$ \\
\hline Morocco & $\mathrm{N}$ & $\mathrm{N}$ \\
\hline Tunisia & $\mathrm{N}$ & $\mathrm{N}$ \\
\hline Saudi Arabia & $\mathrm{C}$ & $\mathrm{C}$ \\
\hline Kuwait & $\mathrm{N}$ & $\mathrm{C}$ \\
\hline Oman & $\mathrm{N}$ & $\mathrm{N}$ \\
\hline Bahrain & $\mathrm{N}$ & $\mathrm{C}$ \\
\hline Jordan & $\mathrm{N}$ & $\mathrm{C}$ \\
\hline Israel & $\mathrm{N}$ & $\mathrm{C}$ \\
\hline Abu Dhabi & $\mathrm{C}$ & $\mathrm{C}$ \\
\hline Qatar & $\mathrm{N}$ & $\mathrm{C}$ \\
\hline
\end{tabular}

The Egyptian, Saudi Arabian and Abu Dhabi markets exhibited evidence of contagion under both models, which confirms their high susceptibility to changes in the U.S. market. Generally, the empirical findings of both models support the results of Lagoarde-Segot and Lucey (2007); and Lagoarde-Segot and Lucey (2009) that MENA countries have heterogeneous and increasing levels of financial vulnerability, as a result of the recent opening up of their capital markets. However, the results obtained from both were not robust, indicating that there is no one definite answer to the question of contagion. Whether contagion exists or not depends on the methodology used and the method of treating missing observations.

\section{AUTHOR INFORMATION}

Loujaina M. El Sayed is an Economist at the Egyptian Ministry of Finance. Before joining the Ministry of Finance, she was an Economic Researcher in the Ministry of International Cooperation. She obtained her B.A. and M.A. degrees in Economics from the American University in Cairo (AUC) in 2008 and 2012 respectively. E-mail: loujaina@aucegypt.edu (Corresponding author)

Nourhan Hegazi is an Economic Researcher at the American Chamber of Commerce (Amcham) in Egypt. Before joining the Amcham, she worked as an Economic Analyst at the Egyptian Ministry of Industry and Foreign Trade. She obtained her B.Sc degree in Economics from the Faculty of Economics and Political Sciences, Cairo University in 2007; and her M.A. in Economics from the American University in Cairo (AUC) in February 2012. E-mail: nhegazi@aucegypt.edu

\section{REFERENCES}

1. Ahlgren, N., and Antell, J. (2010). Stock Market Linkages and Financial Contagion: A Cobreaking Analysis. The Quarterly Review of Economics and Finance, 50(2) 157-166.

2. Baig, T., and Goldfajn, I. (1999). Financial Market Contagion in the Asian Crisis. IMF Staff Papers, 46(2) 167-195.

3. Bouaziz, M., Selmi, N. and Boujelbene, Y. (2012). Contagion Effect of the Subprime Financial Crisis: Evidence From DCC Multivariate GARCH Models. European Journal of Economics, Finance and Administrative Sciences, 22(1-2) 66-76.

4. Business Cycle Dating Committee. (2011). US Business Cycle Expansions and Contractions. Retrieved December 14, 2011, from National Bureau of Economic Research Website: http://www.nber.org

5. Calvo, G. (1998). Capital Market Contagion and Recession: An Explaination of the Russian Virus. College Park, Maryland: University of Maryland.

6. Calvo, G., and Mendoza, E. (2000). Rational Herd Behavior and the Globalization of Securities Markets. Journal of International Economics, 51(1) 79-113.

7. Celik, S. (2012). The More Contagion Effect on Emerging Markets: The Evidence of DCC-GARCH Model. Economic Modelling, 29 (5) 1946-1959.

8. Chiang, T., Jeon, B., Li, H. (2007). Dynamic Correlation Analysis of Financial Contagion: Evidence from the Asian Markets. Journal of International Money and Finance 26(7), 1206-1228. 
9. Cho, J., and Parhizgari, A. (2008). East Asian Financial Contagion under DCC-GARCH. International Journal of Banking and Finance, 6(1).

10. Claessens, S., and Forbes, K. (2004). International Financial Contagion: The Theory, Evidence and Policy Implications. The IMF's Role in Emerging Market Economies: Reassessing the Adequacy of its Resources. Amesterdam.

11. Collins, D., and Biekpe, N. (2003). Contagion: A Fear for African Equity Markets?. Journal of Economics and Business, 55(3) 285-297.

12. Collins, D., and Gavron, S. (2005). Measuring equity market contagion in multiple financial events. Applied Financial Economics, 15 (8) 531-538.

13. Corsetti, G., Pericoli, M. and Sbracia, M. (2005). Some Contagion, Some Interdependence: More Pitfalls in Tests of Financial Contagion. Journal of International Money and Finance, 24(8) 1177-1199.

14. Dungey, M., and Martin, V. (2004). A Multifactor Model of Exchange Rates with Unanticipated Shocks: Measuring Contagion in the East Asian Currency Crisis. Journal of Emerging Market Finance, 3(3) 305330 .

15. Edwards, S. (1998). Interest Rate Volatility, Contagion And Convergence: An Empirical Investigation Of The Cases Of Argentina, Chile And Mexico. Journal of Applied Economics, 1 55-86.

16. Eichengreen, B., Rose, A., and Wyplosz, C. (1996). Contagious Currency Crises. NBER Working Paper no. 5681.

17. Engle, R. (2002). Dynamic Conditional Correlation: A Simple Class of Multivariate Generalized Autoregressive Conditional Heteroskedasticity Models. Journal of Business and Economics Statisitics, 20(3) 339-350.

18. Favero, C., and Giavazzi, F. (2002). Is the International Propagation of Financial Shocks Non- Linear? Evidence from the ERM. Journal of International Economics, 57(1) 231-246.

19. Frobes, K. (2001). Are Trade Links Important Determinants of Country Vulnerability of Crises. National Bureau of Economic Research , Working paper no.194.

20. Forbes, K., and Rigobon, R. (2002). No Contagion, Only Interdependence: Measuring Stock Market Comovements. The Journal of Finance, 57(5) 2223-2261.

21. Girard, E.; and Ferreira, E. (2004). On the Evolution of Inter- and Intraregional Linkages to Middle East and North Africa Capital Markets. Quarterly Journal of Business and Economics, 43(1/2) 21-43.

22. Girard, E.; Omran, M.; and Zaher, T. (2003). On Risk and Return in MENA Capital Markets. International Journal of Business, 8(3).

23. Glick, R., and Rose, A. K. (1999). Contagion and Trade: Why Are Currency Crises Regional? Journal of International Money and Finance, 18(4) 603-617.

24. Hamao, Y., Masulis, R., and Ng, V. (1990). Correlations in Price Changes and Volatility across International Stock Markets. The Review of Financial Studies, 3(2) 281-307.

25. Hernandez, L. and Valdes, R. (2001). What Drives Contagion: Trade, Neighborhood or Financial Links?. International Review of Financial Analysis, 10(3) 203-218.

26. Kaminsky, G. L., and Reinhart, C. M. (2000). On Crises, Contagion, and Confusion. Journal of International Economics, 51(1) 145-68.

27. Kaminsky, G.; Reinhart, C.; and Vegh, C. (2003). The Unholy Trinity of Financial Contagion. Journal of Economic Perspectives, 17(4), 51-74.

28. King, M., and Wadhwani, S. (1990). Transmission of Volatility between Stock Markets . Review of Financial Studies, 3(1) 5-33.

29. Kouame, A. (2009). Update on the Impact of the Global Financial Crisis on Arab Countries. Retrieved December 16, 2011, from World Bank: http://web.worldbank.org

30. Lagoarde-Segot, T.; and Lucey, B. (2007). Capital Market Integration in the Middle East and North Africa. Emerging Markets Finance and Trade, 43(4) 34-57.

31. Lagoarde-Segot, T.; and Lucey, B. (2009). Shift Contagion Vulnerability in the MENA Stock Markets. The World Economy, 32(10) 1478-1497.

32. Lee, S.B., Kim, K.J. (1993). Does the October 1987 Crash Strengthen the Co-Movements Among National Stock Markets? Review of Financial Economics, 3, 89-102.

33. Longin, F., and Solnik, B. (1995). Is the Correlation in International Equity Returns Constant: 1960-1990? Journal of International Money and Finance, 14(1) 3-26. 
34. Masih, A. and Masih, R. (1999). Are Asian Stock Market Fluctuations Due Mainly to Intra-Regional Contagion Effects? Evidence Based on Asian Emerging Stock Markets. Pacific-Basin Finance Journal, 7(3) 251-282.

35. Naoui, K., Liouane, N., and Brahim, S. (2010). A Dynamic Conditional Correlation Analysis of Financial Contagion: The Case of the Subprime Credit Crisis. International Journal of Economics and Finance, 2(3) 85-96.

36. Omri, A., and Frikha, M. (2011). No Contagion, Only Interdependence During the US Sub-Primes Crisis. Transition Studies Review, 18 (2) 286-298.

37. Rodriguez, J. (2007). Measuring Financial Contagion: A Copula Approach. Journal of Empirical Finance. 14(3) 401-423.

38. Sojli, E. (2007). Contagion in Emerging Markets: the Russian Crisis. Applied Financial Economics, 17(3) 197-213.

39. Syllignakis, M. and Kouretas, G. (2011). Dynamic Correlation Analysis of Financial Contagion: Evidence from the Central and Eastern European Markets. International Review of Economics and Finance, 20(4) 717-732.

40. Valdes, R. (2000). Emerging Markets Contagion: Evidence and Theory. Central Bank of Chile Working Paper No. 7. Retrieved from: http://papers.ssrn.com/sol3/papers.cfm?abstract id=69093

41. Van Rijckeghem, C., and Weder, B. (1999). Source of Contagion: Finance or Trade? International Monetary Fund, Working Paper no.146.

42. Yiu, M., Ho, W., and Choi, D. (2010). Dynamic Correlation Analysis of Financial Contagion in Asian Markets in Global Financial Turmoil. Applied Financial Economics 20(4). 345-354. 